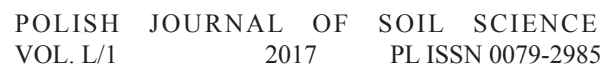

DOI: $10.17951 / \mathrm{pjss} / 2017.50 .1 .83$

\title{
KACPER RYGIELSKI*, KRYSTYNA CYBULSKA* \\ THE CONTENT OF LIVE MICROBIAL BIOMASS IN THE SOIL IN CASE OF VARIOUS CROPS ON THE EXAMPLE OF THE FARM IN STARZA
}

Abstract. As it is well known, the share of microorganisms in the fertility and soil health is very important. Soil microorganisms play a major role in organic matter mineralization, provide nutrients to plants, and improve the soil structure. The size of the soil organisms is very variable. It depends primarily on the water and air relations in the soil as well as the temperature.

The aim of the research was to determine the content of live microorganisms biomass in the soil under rape, maize, bean and wheat crops including the rhizosphere. The analyzes were carried out in different vegetation periods and phases of plant development on the example of the farm in Starza.

Determination of living microorganisms biomass was carried out applying the method developed by Anderson and Domsch. The biomass content of live microorganisms in the soil was dependent on the cultivated plant, growing date and phase, as well as the proximity of the rhizosphere.

Keywords: rhizosphere, biomass,microorganisms, soil

\section{INTRODUCTION}

In the history of his development, man used various methods of soil cultivation to maintain its fertility and increase yields (Pudełko et al. 1994). Observing the tendencies of transformation and development of agrotechnics, an intensive search for methods that would allow the farmer to modify the current cropping

* Department of Chemistry, Microbiology and Environmental Biotechnology, West Pomeranian University of Technology, kacper.rygielski@zut.edu.pl 
systems, or even the transition from conventional agriculture to agriculture that would be economically, ecologically, and socially viable, is clearly noticeable.

The progress in contemporary civilization reflects the rate of the unconscious action of depriving the soil of the ability to naturally regenerate and sustain it in a state of high productivity. More often, there is a shift towards seeking and restoring biological technologies in agriculture (Mrugalska et al. 2009). In many countries, agricultural chemistry is being given up and biological diversity in nature is restored. New, effective, non-invasive, and broad-spectrum methods are being sought to protect plants from pests as well as to stimulate plant resistance to diseases and meteorological conditions.

Soil as an important element of the natural environment makes favorable conditions for microbial life and macrofauna. The soil microorganisms and, above all, bacteria and fungi, which in the process of organic matter mineralization release biogens, are responsible for increasing the soil fertility (Kostuch 1997). The soil also contains microorganisms necessary for some plants, such as symbiotic papillary bacteria of the legume plants, and, at the same time, may have various organisms that are undesirable or harmful to plants (Jabłoński 1980).

The soil structure consists of the following fractions (Fig. 1):

- mineral substances $(45 \%)$ resulting from weathering of rocks, occurring in the form of colloids composed of aluminosilicates, hydrated silica, and aluminum and iron hydroxide;

- organic compounds (5\%), mainly humic compounds, resulting from the microbiological degradation of plant and animal residues, occurring in colloidal form;

- water $(30 \%)$ forming together with dissolved organic and inorganic compounds, the soil solution of varied composition and buffer properties to limit excessive acidification or alkalinization of the soil;

- gaseous phase $(20 \%)$ filling free space between solid particles, containing primarily $\mathrm{N}_{2}, \mathrm{O}_{2}, \mathrm{NH}_{3}, \mathrm{CO}_{2}$;

- living and dead organisms (Kostuch 1997).
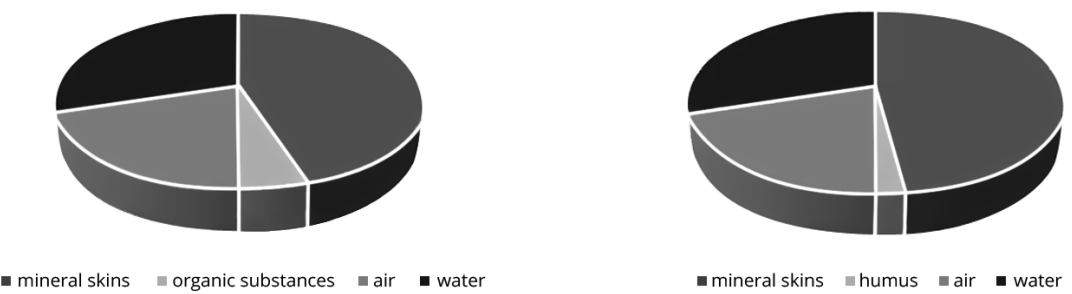

Fig. 1. The average composition of individual soil fractions: mineral (left) and organic (right), Kołwzan et al. (2005).

The number of soil organisms is very variable. It depends primarily on the water and air relations in the soil, as well as other factors. During the year, we 
can distinguish two periods of increased microbial growth: spring and autumn. This is due to a favorable arrangement of water and thermal conditions. An additional factor in the fall season is the high content of crop residues in soil (Jabłoński 1980). The overall mass of microorganisms in the soil layer of $20 \mathrm{~cm}$ thick in the area of 1 ha is several to several dozen tons, and one gram of soil can contain even up to several to tens of millions of cells (Kermen 1981). Number of microorganisms in the soil is decreasing with the distance from the surface practically approaching zero at a depth of 1-2 m. A numerous soil microflora population can still be found around the roots of trees and in legume crops the root systems of which go much deeper (Mostowik 2007).

In modern field crop production, microorganisms play the role of an agronomic element in simplified farming systems. In addition, the introduction of stubble intercropping for plowing increases the biomass of soil microorganisms and their enzymatic activity. Plants or their biomass brought into the soil stimulate, among others, the development and biological diversity of soil microflora and fauna; during decomposition they release the nutrients used by a succeeding plant and also act positively towards the soil structure. Soil microorganisms are an integral part of the soil and play a number of functions in key processes for the flow of energy and circulation of matter in the environment. They respond quickly to environmental stresses, but they also adapt easily to new conditions. The biochemical activity of soil microorganisms is often considered to be an early signal to reduce or improve the soil quality and productivity. The contribution of microbes in the formation of fertility and soil health is well known, thus, it is necessary to know the effects of factors that directly affect their abundance and activity in the soil (Stockdale and Brookes 2006, Quemada and Menacho 2001).

Rhizosphere is a soil that is affected by secretions of the root system and inhabiting microorganisms that use root secretions as a source of carbon, nitrogen and energy (Brimecombe et al. 2007, James et al. 1985). The rhizosphere zone is one of the most biologically active areas, characterized by abundant bacterial and fungal flora and having a strong influence on the uptake of nutrients by roots (Jurkiewicz et al. 2004).

Microorganisms produce specific biological characteristics of a given plant around the roots, which promotes its development. They form a kind of sheath around the root that makes it easy, and often necessary, to take nutrients by roots from the soil. It also protects them against diseases, negative effects of climate factors such as drought. In the rhizosphere, there are many fungi that closely coexist with the roots of plants (Smith and Read 1997, Lugtenberg and Kamilova 2009). Microbial activity plays a very important role in life of plants, and they visually influence the development of soil microorganisms. Plants form a soil microflora and affect the microbiological changes that are constantly occurring in this environment (Wolińska 2010). Rhizosphere is a privileged place of interaction between soil microorganisms and plants (Pietr 1990). The rhizosphere 
bacteria can stimulate plant growth through the supply of minerals and synthesis of phytohormones that stimulate their development, as well as lowering the levels of ethylene that adversely affect the rooting of plants (Rajkumar et al. 2006).

An important role in increasing the effectiveness of plant production as well as the ability to settle and survive plants in natural environments is played by microorganisms which enter into various types of non-antagonistic interactions with plants. The best known of them are mutualistic symbiotic systems that bring benefits to both participants, or commensalism that is beneficial to one part, but neutral to the other (Strobel 2004).

As suggested by Głażewska-Maniewska et al. (2004), microorganisms develop in a close interdependence with plants from the time of seed germination until the plant reaches its full maturity, and that interdependence may be neutral to plants or exert a beneficial or detrimental impact on their growth.

\section{MATERIALS AND METHODS}

The study was carried out in the farm in Starza, Świerzno commune. The content of living microorganisms in the soil under different crops was evaluated (faba bean, maize, rape, and wheat). The soil samples were collected at various vegetation periods (I date - April 19, 2015 at the beginning of plant vegetation, II date - June 14, 2015 at full vegetation, III date - July 13, 2015 except maize, soil samples were collected on September 21, 2015 i.e. just prior to harvest) from the depth of about $10 \mathrm{~cm}$. Two sampling zones were assigned: rhizosphere and zone free from roots between growing plants.

Soil moisture was determined by disc method: aliquot of $10 \mathrm{~g}$ soil from beneath every experimental combination was weighed. The soil sample was put to the drier at $105^{\circ} \mathrm{C}$ for about 5 hours till constant weight. Then after drying, closed vessels with samples were weighed, while weight of empty vessel was known.

The soil moisture content was recalculated according to the formula:

$$
w=\frac{m \times m_{0}}{m_{0}} \times 100 \%
$$

$\mathrm{m}$ - weight of moist material before drying;

$\mathrm{m}_{0}$ - weight of material after drying.

The Substrate Induced Respiration method (SIR) was applied to determine the weight of living microorganisms. Soil samples weight $10 \mathrm{~g}$ were homogenized with glucose and talc mixture at 1:5 ratio. Soil samples were transferred to Ultragas U4S analyzer in order to measure the level of carbon dioxide emission over three hours. After particular time, the released $\mathrm{CO}_{2}$ was measured in $\mathrm{mm}$. 
Achieved values were recalculated onto $\mathrm{cm}^{3} \mathrm{CO}_{2}$ released during an hour, and amount of living microorganisms biomass in soil was calculated based on the formula given by Anderson and Domsch (1978):

where:

$\mathrm{X}=40.04 \mathrm{Y}+0.37$

$\mathrm{X}$ - biomass of living organisms ( $\mathrm{mg} \mathrm{C} \cdot(100 \mathrm{~g})^{-1} \mathrm{DM}$ of soil);

$\mathrm{Y}$ - maximum initial release of $\mathrm{CO}_{2}\left(\frac{\mathrm{cm}^{3}}{h} \times 100 \mathrm{~g}\right.$ DM of soil).
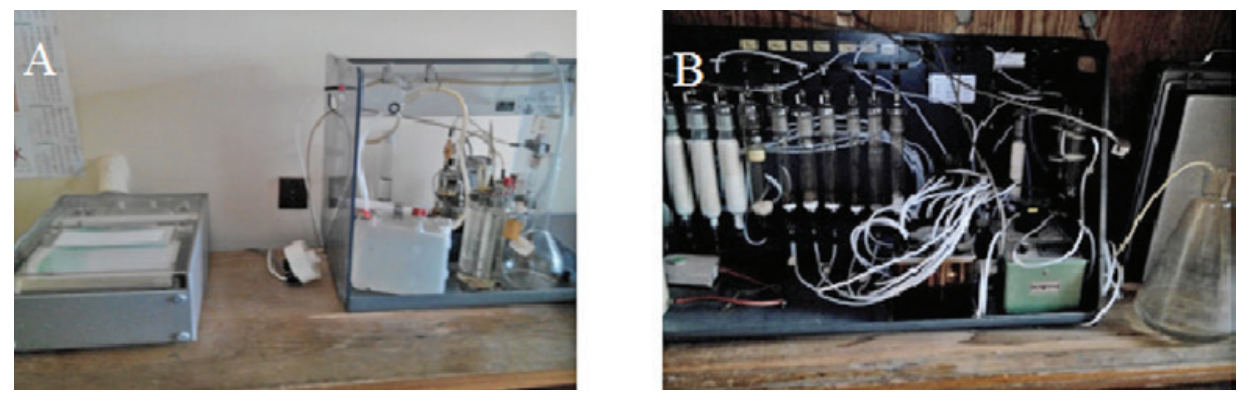

Photo 1. Ultragas U4S device (Wosthoff OHG) (A) and measuring columns for Ultragas U4S device (B)

\section{RESULTS AND DISCUSSION}

The tests revealed that the content of living microorganisms biomass in the soil differed depending on the crop and sampling date.

At the beginning of vegetation period, the content of living microorganisms ranged from $686 \mathrm{mg} \mathrm{C}^{\circ}(100 \mathrm{~g})^{-1}$ to $1.972 \mathrm{mg} \mathrm{C} \cdot(100 \mathrm{~g})^{-1}$. The highest value was recorded under faba bean, then rape and wheat, while the lowest under maize cultivation. The biomass content was also found between soil free from plants and compared rhizosphere.

On the second study date - full vegetation-the content of biomass in soil referred to as free non-rhizosphere zone, the microorganisms biomass content oscillated within $415-1,027 \mathrm{mg} \mathrm{C} \cdot\left(100 \mathrm{~g}^{-1}\right.$ (Fig. 2).

Differences in living microorganisms biomass content in rhizosphere were still similar to springtime, whereas its development increased for such crops as rape and wheat. In the case of faba bean, the content of rhizosphere biomass was close to the level of free (no plants) zone.

At the end of vegetation period (III date) - before crop harvest - the biomass quantity ranged from $741 \mathrm{mg} \mathrm{C} \cdot(100 \mathrm{~g})^{-1}$ up to $1,587 \mathrm{mg} \mathrm{C} \cdot(100 \mathrm{~g})^{-1}$. Also in this case, the highest value was recorded for faba bean cultivation and over $40 \%$ biomass content was determined under rape and wheat (Fig. 2). 

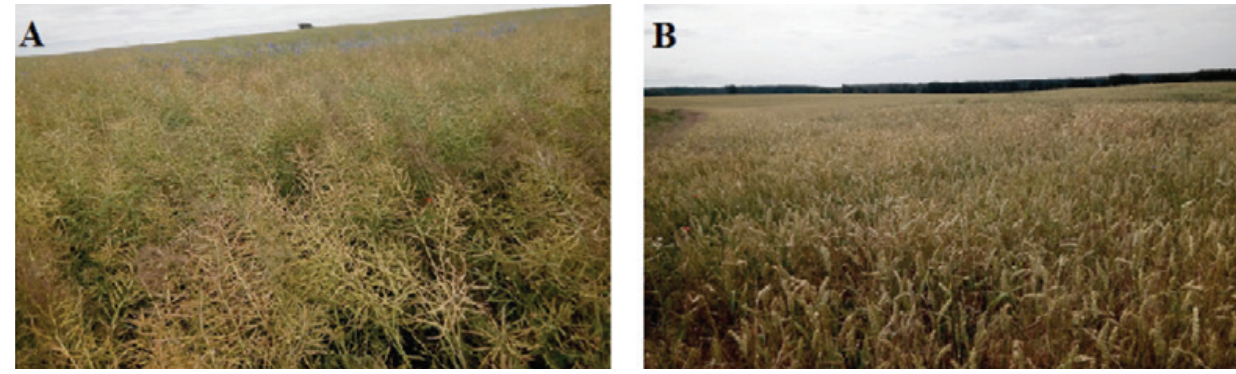

Photo 2. Rape (A) and wheat (B) crops.

When comparing the microbial development within the rhizosphere of such crops as rape or faba bean, it was similar to that in soil free of plants. In the case of wheat rhizosphere, the content of biomass was still high like for spring-summer period amounting to $50 \%$ more than in soil free from plants. The phenomenon of an intensive microorganisms reproduction in the soil was observed in rhizosphere of maize on the third testing date, when it was by $60 \%$ more as compared to the control soil.
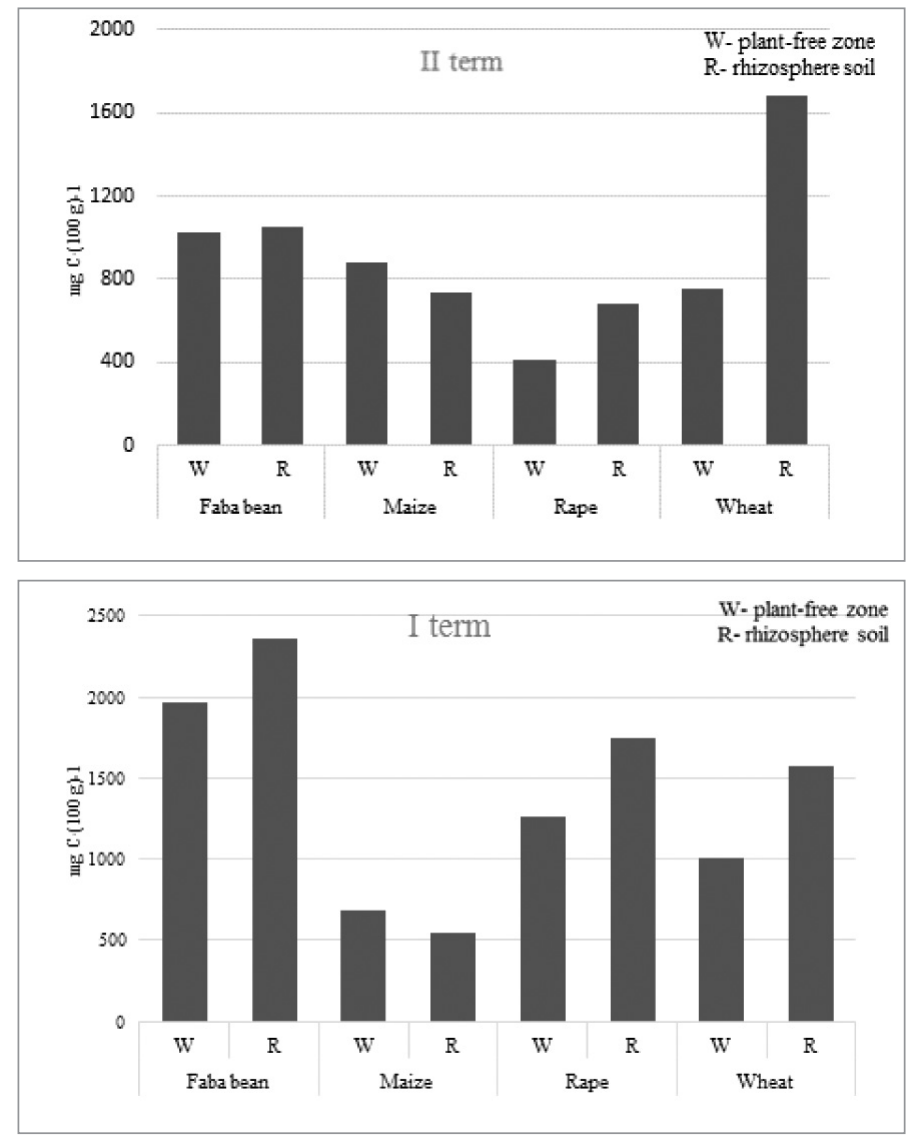


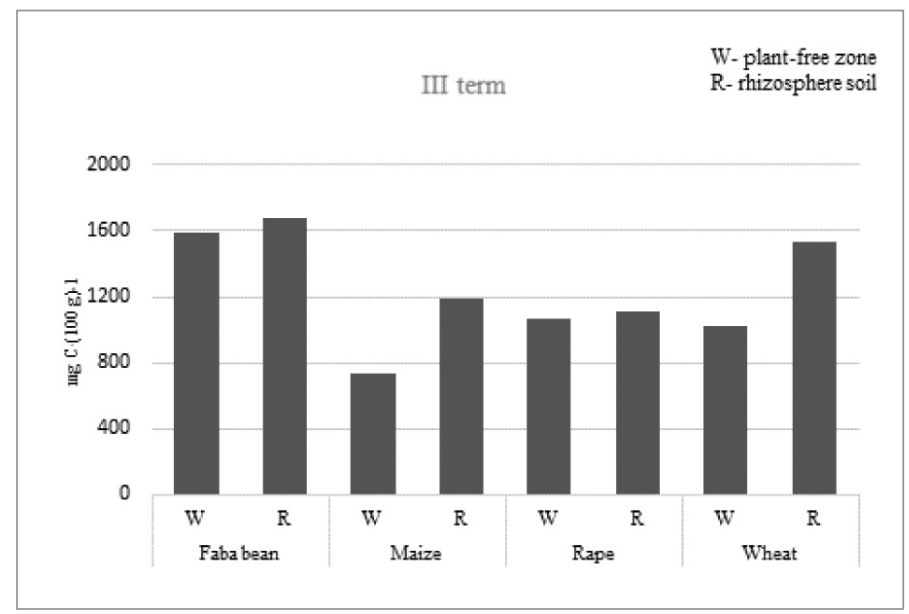

Fig. 2. The content of living microorganisms biomass in the soil under crops at various vegetation periods (I - beginning of vegetation; II - full vegetation; III - prior to harvest)

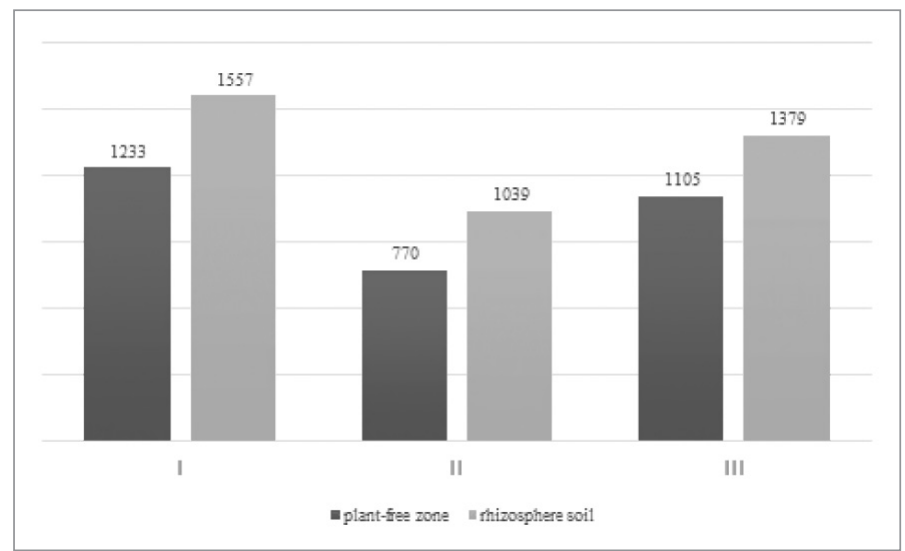

Fig. 3. The average content of biomass on particular testing dates in $\mathrm{mg} \mathrm{C} \cdot(100 \mathrm{~g})^{-1}$ of soil

Contents of the biomass on different testing dates differed to one another (Fig.3). The largest development of microbial development occurred in spring, which amounted to $1,395 \mathrm{mg} \mathrm{C} \cdot(100 \mathrm{~g})^{-1}$ of soil. Lower biomass content (by $11 \%$ ) was recorded on the III testing date (autumn - before crop harvest). The poorest soil microorganism activity in tested objects in the farm Starza was determined in summer, which was by $35 \%$ lower as compared to the springtime. The results were confirmed by Jabłoński (1980), who emphasized that there are two periods of microorganism growth during the vegetation of crops: spring and autumn. It is associated with beneficial thermal and water conditions. 


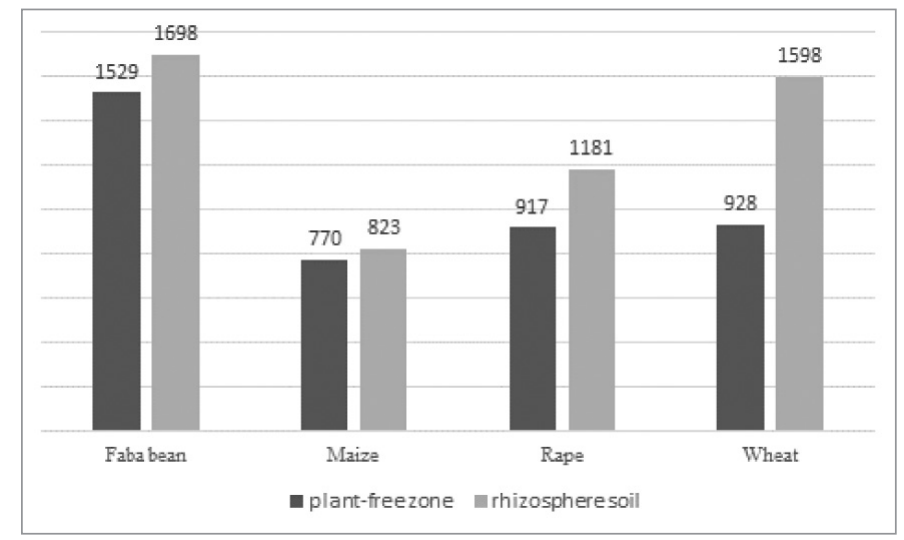

Fig. 4. The average content of living microorganisms biomass in $\mathrm{mg} \mathrm{C} \cdot(100 \mathrm{~g})^{-1}$ of soil for particular crops

The content of living microorganism biomass in the soil under particular cultivations in the farm Starza considerably differed to one another (Fig. 4).

The highest average microbial content of $1,614 \mathrm{mg} \mathrm{C} \cdot(100 \mathrm{~g})^{-1}$ of soil was recorded under faba bean. According to Mostowik (2007), papilionaceous crops are characterized by intensive reproduction of soil microflora. Almost half the value was found in the case of maize. Moderate levels were determined in wheat and rape growing - from $20 \%$ to $35 \%$ less as compared to that for faba bean cultivation.
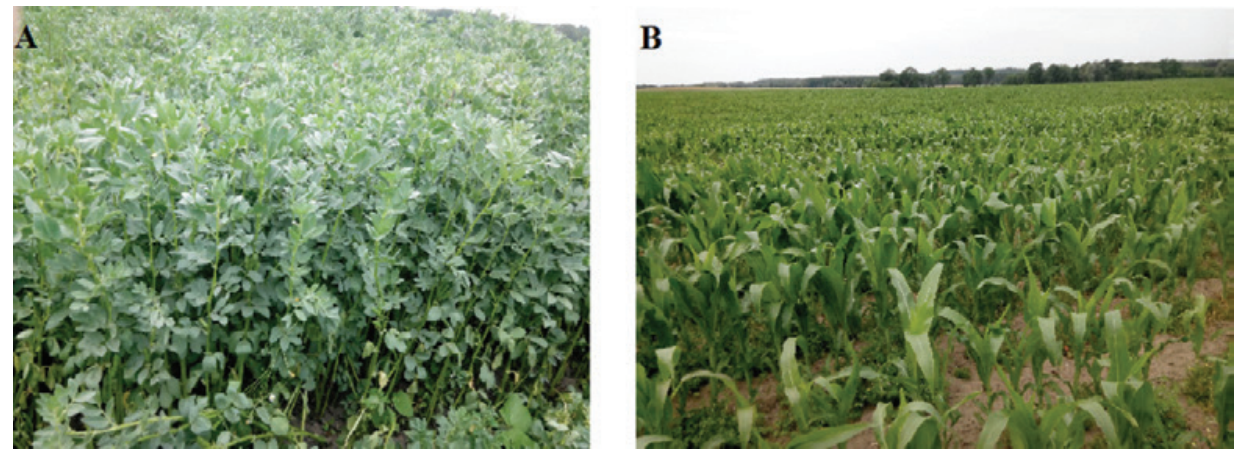

Photo 3. Faba bean (A) and maize (B) cultivation

Based on the study, the rhizosphere of tested crops (faba bean, maize, wheat, and rape) contained the average content of microorganism biomass that was always higher as compared to soil free from plant rhizosphere (Fig. 5).

Wheat had the most inhabited rhizosphere; its mean microorganism biomass content was almost $80 \%$ higher than control. Microbial content appeared to be by $50 \%$ lower in relation to wheat in the case of rape cultivation. Its level was higher by several per cent in the rhizosphere of faba bean and maize than in 


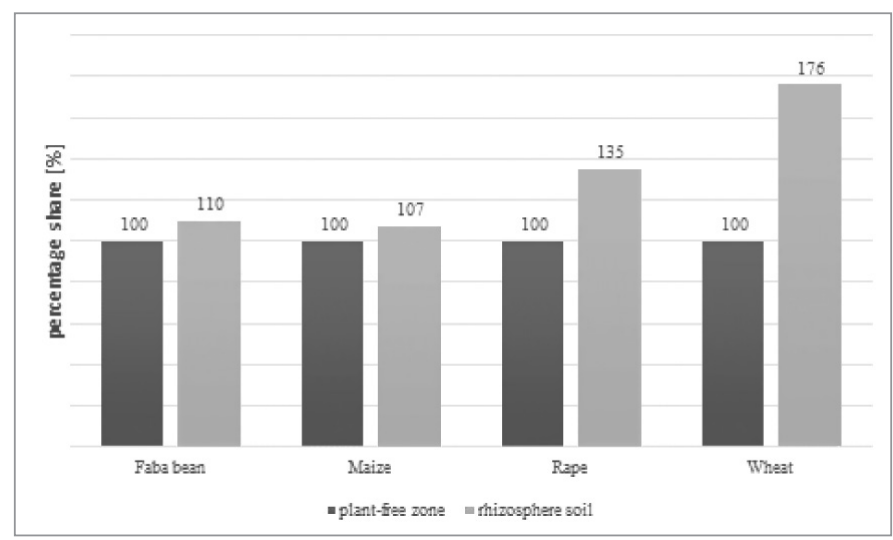

Fig. 5. The content of living microorganisms biomass in rhizosphere of crops and free zone as a control (W - plant-free zone; $\mathrm{R}$ - rhizosphere soil)

free zone. However, it should be noted that in the case of maize, the most intensive development occurred at the end of vegetation on III testing date (Fig. 2). The factor that determined the soil microorganisms reproduction was precipitation that occurred at the end of the study and delayed sowing dates.

According to Mostowik (2007), the number of microorganisms in the soil decreases with the distance from surface. As it is commonly known, wheat has a well-developed root system of a bundle type. Rhizosphere is a privileged site of the interaction between soil microorganisms and plants (Pietr 1990). Microorganisms produce specific environment around roots, which favors their development (Pudełko et al. 1994).

\section{CONCLUSIONS}

1. The content of living microorganisms biomass depended on the crop, growing phase, and rhizosphere zone, as compared to the soil free from plants.

2. The most intensive development of microorganisms in soil occurred in spring $-1,395 \mathrm{mg} \mathrm{C} \cdot(100 \mathrm{~g})^{-1}$, then in autumn $-1,242 \mathrm{mg} \mathrm{C} \cdot(100 \mathrm{~g})^{-1}$, while considerably less in summer $-905 \mathrm{mg} \mathrm{C} \cdot(100 \mathrm{~g})^{-1}$.

3. The highest content of microbial biomass was recorded under faba bean cultivation (mean 1,613 $\left.\mathrm{mg} \mathrm{C} \cdot(100 \mathrm{~g})^{-1}\right)$, then wheat $\left(1,263 \mathrm{mg} \mathrm{C} \cdot(100 \mathrm{~g})^{-1}\right)$ and rape $\left(1,049 \mathrm{mg} \mathrm{C} \cdot(100 \mathrm{~g})^{-1}\right)$, as well as maize $\left(797 \mathrm{mg} \mathrm{C} \cdot(100 \mathrm{~g})^{-1}\right.$, on average).

4. Considering the rhizosphere of crops, the largest development of microorganisms was recorded for wheat and rape as well as faba bean, particularly at the beginning of vegetation and full development phase. The adverse tendencies of living microorganisms biomass development were observed for maize rhizosphere, where they reproduced the most intensively at the end of crop vegetation period. 


\section{REFERENCES}

[1] Brimecombe, M.J., De Leij, F.A.A.M., Lynch, J.M., 2007. Rhizodeposition and Microbial Populations. In: Pinton, R., Varanini, Z., Nannipieri P. (eds.),The Rhizosphere: Biochemistry and Organic Substances at the Soil-Plant Interface. CRC Press, Taylor \& Francis Group, Boca Raton, London, New York, pp. 73-109.

[2] Głażewska-Maniewska, R., Maciejewska, A., Melech, A., 2004. Occurrenceof Soil Bacteria of Arthrobacter Ssp. Genus on Winter Rye Plantation and Their Enzymatic and Antagonistic Activity. Acta Scientiarum Polonorumseria Agricultura, 3, 1: 129-37.

[3] Jabłoński, B., 1980. General Soil and Plant Cultivation. State Agricultural and Forestry Publishing House. Warsaw, 68, 109-111.

[4] James, D.W., Suslow, T.V., Steinback, K.E., 1985. Relationship Between Rapid, Firm Adhesion and Long-Term Colonization of Roots by Bacteria. Appl. Environ. Microbiol. 50: 392-397.

[5] Jurkiewicz, A., Orłowska, E., Anielska, T., Godzik,B., Turnau, K., 2004. The Influence of Mycorrhiza and EDTA Application on Heavy Metal Uptake by Different Maize Varieties. Ser. Bot., 46: 7-18.

[6] Kermen, J., 1981. Dynamic Balance of Microorganisms in the Soil. Post. Mikrobiol., 20, 3/4: 202.

[7] Kołwzan, B., Adamiak, W., Grabas, Pawełczyk, A., 2005. Fundamentals of Microbiology in Environment Protection. Ofic. Wyd. PWr, 8.

[8] Kostuch, R., 1997. What are the Endangered Soils? Ecoengineering, 9: 18-20.

[9] Lugtenberg, B, Kamilova F., 2009. Plant-Growth-Promoting Rhizobacteria.Annu Rev Microbiol., 63: 541-56, DOI.org/10.1146/annurev.micro.62.081307.162918

[10] Mostowik, K., 2007. Technical Microbiology. Vol.1. PWN, Warsaw, pp. 190-194.

[11] Mrugalska, L., Owczarzak, W., Kaczmarek, Z., 2009. The Impact of Effective Microorganisms on the Process of Soil Structure Forming in the Incubatory Experiment. J. Res. Appl. Agric. Engng., 54, 4: 26-31.

[12] Pietr S., 1990. Impact of Saprophytic Microflora of the Rhizosphere on Plant Growth. Post. Nauk Roln., 3: 19-38.

[13] Pudełko, J., Wright, D.L., Wiatrak, P., 1994. Using of Restrictions in Soil Tillage in the United States AP. Post. Nauk Roln., 1: 153-162.

[14] Quemada, M., Menacho, E., 2001. Soil Respiration 1 Year after Sewage Sludge Application. Biol. Fertil. Soils, 33: 344-346.

[15] Rajkumar, M., Nagendra, R., Lee, K.J., Lee, W.H., Kim, S.Z., 2006. Response of Endophytic Growth Promoting Bacteria and Cr6+ on the Growth of Indian Mustard. Chemosphere, 62: 741-748, DOI: 10.1016/j.chemosphere.2005.04.117

[16] Smith, S.E., Read, D.J., 1997. Mycorrhizal symbiosis, $2^{\text {nd }}$ ed. Academic Press, London

[17] Stockdale, E.A., Brookes, P.C., 2006. Detection and Quantification of the Soil Microbial Biomass - Impacts on the Management of Agricultural Soils. Journal of Agr. Sci., 144, 4, DOI: 10.1017/S0021859606006228

[18] Strobel, G., Daisy, B., Castillo, U., Harper, J., 2004. Natural Products from Endophytic Microorganisms. J. Nat. Prod., 67: 257-268, DOI:10.1021/np030397v

[19] Wolińska, A., 2010. Dehydrogenase Activity of Soil Microorganisms and Availability of Oxygen in the Process of Reoxidation of Selected Mineral Soils in Poland, Rozpr. Monogr.,180, 3. 